The University of San Francisco

USF Scholarship: a digital repository @ Gleeson Library |

Geschke Center

Economics

College of Arts and Sciences

2014

\title{
Do Risky Microfinance Borrowers Really Invest in Risky Projects? Experimental Evidence from Bolivia.
}

Eliana Zeballos

Alessandra Cassar

University of San Francisco, acassar@usfca.edu

Bruce Wydick

University of San Francisco,wydick@lucas.usfca.edu

Follow this and additional works at: http://repository.usfca.edu/econ

Part of the Economics Commons

\section{Recommended Citation}

Eliana Zeballos, Alessandra Cassar \& Bruce Wydick. Do Risky Microfinance Borrowers Really Invest in Risky Projects? Experimental Evidence from Bolivia. The Journal of Development Studies Volume 50, Issue 2, 2014. DOI: 10.1080/00220388.2013.858124

This Article is brought to you for free and open access by the College of Arts and Sciences at USF Scholarship: a digital repository @ Gleeson Library | Geschke Center. It has been accepted for inclusion in Economics by an authorized administrator of USF Scholarship: a digital repository @ Gleeson Library | Geschke Center. For more information, please contact repository@usfca.edu. 


\title{
Do Risky Microfinance Borrowers Really Invest in Risky Projects? Experimental Evidence from Bolivia
}

\author{
JEL Classifications: C9, O16, G21 \\ Keywords: Credit Markets, Microfinance, Asymmetric Information, Experimental Economics \\ Eliana Zeballos* Alessandra Cassar** Bruce Wydick****
}

May 6, 2013

\begin{abstract}
This paper reports the results of an experiment designed to test a fundamental assumption in Stiglitz and Weiss (1981) model of credit rationing, that defaulting borrowers are associated with investment in risky projects. Through an artefactual field experiment with 200 Bolivian microfinance borrowers, we observe that subjects from real-world delinquent borrowing groups do not prefer risky projects to safer ones significantly more than subjects from repaying groups. Moreover, when faced with the choice between two options framed as consumption or a relatively safe investment project, risky borrowers significantly opt more for consumption, supporting more recent behavioral theories of credit market failure. This result has important implications for our understanding of microfinance in developing countries: defaulting microfinance borrowers may be those that take too little investment risk rather than those who take too much.
\end{abstract}

*Eliana Zeballos: Innovations for Poverty Action, Mexico City, Mexico, Doctoral Student, Department of Agricultural and Resource Economics, University of California at Davis, e-mail: eliana.zeballos@gmail.com

**Alessandra Cassar: Associate Professor, Department of Economics, 407 Cowell Hall, University of San Francisco, 2130 Fulton Street, San Francisco, CA 94117, e-mail: acassar@usfca.edu.

***Bruce Wydick: Professor of Economics, 410 Cowell Hall, University of San Francisco, 2130 Fulton Street, San Francisco, CA 94117, Visiting Professor, Department of Agricultural and Resource Economics, University of California at Berkeley, e-mail: rydick@usfca.edu.

This work was funded by the University of San Francisco's graduate program in International and Development Economics. We wish to thank Giorgia Barboni and Arturo Rodriguez for outstanding assistance with research experiments, and PORVENIR in Bolivia for permission to run experimental research among its clients. We also thank Travis Lybbert, Craig McIntosh and Pauline Grosjean for helpful comments, insight, and input into this research. 
"Poor people are not credit worthy... they will not be able to pay back... no matter how much money you give, they will eat and the money will be over, they can't pay you back."

Muhammad Yunus, on how banks justify denying credit to the poor

\section{INTRODUCTION}

In one of the most celebrated papers in economics, Stiglitz and Weiss (1981) develop a model of credit markets that demonstrates how adverse selection and moral hazard emerge under asymmetric information to create incentives for borrowers to invest in risky projects. This incentive to undertake risky projects forms the basis for a credit rationing equilibrium in which many borrowers who desire to take loans at the market interest rate are denied. The model has been applied extensively as a basis for understanding the nature of microfinance markets in developing countries, and even as a motivation for microfinance itself; indeed a recent search in Google scholar showed 1,070 papers that discuss the Stiglitz and Weiss model in the context of microfinance.

The question of whether or not the Stiglitz and Weiss model holds for microfinance has important policy implications for development economics as well as development practice. Fundamentally, it affects the way we think about delinquency in microfinance: Are risky microfinance borrowers those who take too much risk, or, as more recent behavioral economics research suggests, are risky microfinance borrowers those who favor the safety of consumption over investment and thus in some sense take on too little risk?

In this paper we report the results of an artefactual field experiment designed to investigate the characteristics of borrowers that a microfinance institution would consider "risky", borrowers who are members of delinquent groups that failed to repay in time. In particular, we are interested in testing Stiglitz and Weiss' (1981) assumption underlying credit market failure: that risky borrowers are those who invest in risky projects. We proceed by 
testing whether there is any correlation between borrowers that a bank considers risky and their choices of riskier vs. safer projects (moral hazard), consumption vs. investment (cheating moral hazard), or homegrown preference towards risk (adverse selection).

We carried out an artefactual field experiment among 200 Bolivian microfinance borrowers from PORVENIR, S.A., a microfinance institute in El Alto, Bolivia. The sample of subjects was purposely stratified to include a large number of real-world delinquent borrowers: three-fifths of our subjects were members of small borrowing groups who had experienced significant problems with timely loan repayment. The remaining subjects, whom we will refer to as "safe borrowers," came from borrowing groups without any difficulties in loan repayment.

The experiment was framed as a microfinance loan assigned to each subject. Each subject participated in two distinct treatments administered in random order. ${ }^{1}$ In a first treatment, individual borrowers were asked to choose between investing in either: 1) a risky project with a low probability of a high return, or 2) a safer investment project with a high probability of a lower return. In a second treatment (carried out in random order with the other treatments to prevent learning order-effects), the same borrowers were presented with a choice between: 1) investing the loan in the safer investment project, or 2) not investing the loan but rather use it for "consumption" (a certain payoff that involved delinquency).

Our results reveal no evidence that real-world risky borrowers (subjects from realworld delinquent groups) have a tendency to prefer risky choices or to be endowed with risk tolerance preferences higher than the rest. On the contrary, we find that they prefer safer choices and, when faced with the "consumption” vs. a relatively safe investment option, they prefer to consume their loans at a rate nearly double that of the safe borrowers $(30 \%$ vs. $18 \%$, $p=0.06)$. In short, our results find no empirical support for the assumptions that underpin the

\footnotetext{
${ }^{1}$ The complete experiment consisted of several other treatments designed to investigate other aspects of moral hazard and self-selection in group-settings. These treatments and results are described in a companion paper (Barboni., Cassar, Rodriguez, and Wydick, forthcoming).
} 
Stiglitz and Weiss credit model. Instead, our results offer some evidence that the fundamental source of moral hazard in credit markets appears to lie in diverting loans from investment to consumption, consistent with some more recent models of behavior in credit markets (e.g. Bertrand et al. 2005; Ashraf et al. 2006; Gugerty 2007; and Banerjee and Mullainathan 2010). According to these newer models, moral hazard in credit transactions is not related to the temptation to invest in risky projects, but rather in the temptation to consume borrowed capital instead of investing it in productively.

Whether the behavior underlying the traditional model or the newer behavioraleconomics-based models is better able to explain the origin of default has important implications for microfinance policy. If the basis of microfinance default lies in the temptation of using loans for present consumption rather than undertaking risky projects, then training loan officers to dissuade microfinance borrowers from investing in risky projects will have little impact on default. On the contrary, our experimental results suggest that, to reduce microfinance default, practitioners should encourage borrowers to engage in the normal risks associated with entrepreneurial investment rather giving in to the temptation to use loans for household consumption.

\section{RELATED LITERATURE}

The Stiglitz and Weiss (1981) model of credit market failure presents a type of moral hazard in which borrowers, due to a convex payoff function over returns, have an incentive to invest in risky projects over safer ones. This incentive is at odds with the interests of lenders, who, given their concave payoff function over borrower returns, would prefer borrowers to invest in safer projects to increase the probability of loan repayment. In their model, riskier borrowers are willing to pay higher interest rates because they realize higher rates of return in the good states of nature, but are insulated from losses under joint liability in the bad state of 
nature. Credit rationing occurs because lenders have an incentive to keep interest rates at submarket-clearing levels in order to bring safer projects back into the pool.

This "risky-versus-safe project" framework has had a powerful influence on the development economics literature and has become a theoretical starting point in textbook chapters on credit markets for leading undergraduate and graduate texts in development economics (for example, Ray, 1997; Bardhan and Udry, 1999) and microfinance (Armendáriz and Morduch, 2005; 2010). This "risky-versus-safe project" framework has given birth to theories regarding the ability of group lending to mitigate problems of adverse selection and moral hazard. Stiglitz (1990) argues that the peer monitoring advantages inherent in group lending dissuade borrowers from undertaking investments in risky projects. The same framework underlies the foundation of Banerjee, Ghatak, and Guinnane's (1994) model of peer monitoring in early German credit cooperatives. Adverse-selection-based group lending models developed by Ghatak (1999, 2000), Van Tassel (1999), Ghatak and Guinnane (2001), and Armendáriz de Aghion and Gollier (2000) all adopt the risky-versus-safe projects framework to demonstrate the potentially advantageous self-selection properties of group lending and its ability to screen borrowers with risky projects from a lender's portfolio. Early empirical work on group lending such as Wenner (1995) and Wydick (1999) implicitly adopts the Stiglitz and Weiss framework to ascertain whether group lending is able to improve borrower repayment via selection and internal enforcement mechanisms. The model has also formed the basis of experimental design in recent experimental work in microfinance, such as Giné et al. (2010).

In contrast, the real fear of many practitioners in developing countries doesn't appear to be that borrowers would take too much investment risk with borrowed capital, rather too little risk. One of the main reasons given by formal lenders for not lending to the poor is the fear these borrowers who lack collateral would not invest the loan but instead direct it for consumption needs. According to Yunus (1995), the traditional fear among formal lenders has 
been that the poor lack the self-discipline to abstain from consumption when in possession of a large sum of money intended for productive investment. While these views tend to be reported more anecdotally than in the academic literature, they are pervasive enough to warrant investigation.

The idea that consumption-based moral hazard might constitute a greater source of moral hazard than the fear of investment in projects that are too risky makes economic sense in many contexts involving lending, such as, but not limited to microfinance. First of all, the type of activity in which microfinance borrowers invest is more often than not an exogenous choice, determined by a rather fixed set of skills and identity: A baker will invest in an oven; a vendor selling pants will buy boxes of pants. Second, since the type of business operated by the borrower is known by the loan officer, the type of project in which a borrower invests is one of the more salient components of a credit transaction. On the contrary, much more susceptible to hidden action is the diversion of all or part of the loan from the investment activity toward household consumption.

This kind of consumption-based moral hazard is cited by both practitioners and many recent theories about saving and borrowing such as Ashraf et al. (2006), Bertrand et al. (2005), and Banerjee and Mullainathan (2010). This research tends to view the problem of saving, borrowing, and investment as a self-control issue. Microfinance loans are seen as commitment devices to keep resources directed toward capital with payoffs in the future and away from consumption goods--especially "temptation goods"--that have a payoff only in the present. From this perspective, microfinance contracts may function as a device that commits borrowers to a series of formal payments to finance a productive capital investment. For example, one of the principal advantages of non-profit microfinance, which often places an emphasis on building entrepreneurial capacities, may be that the esprit de corps of training sessions create a collective reference point around successful entrepreneurialism and loan repayment. Another 
advantage of group lending (even without joint liability) may be the recurrent "nudge" by the other members to focus one another on timely repayment and away from the temptation of using current liquidity for current consumption. Seen in this light, borrowing may just be another form of saving, but embodied in a stronger commitment device.

This temptation to divert credit granted for business investment to household consumption has empirical support. For example, in a sample of 1,672 microfinance households in Guatemala, India, and Ghana, McIntosh et al. (2011) find that among borrowers who had taken loans officially for business investment, the probability of a television set purchase rose 1.7 percentage points (over a baseline probability of only 4.3 percentage points) in the first year that a microfinance loan was taken.

\section{EXPERIMENTAL DESIGN}

\subsection{SAMPLE}

The data reported in this paper come from an artefactual field experiment and survey carried out in Bolivia during July and August 2009. Our subject pool consists of 200 borrowers from PORVENIR S.A., a medium-sized Bolivian microfinance institution located in El Alto, a northeastern suburb of La Paz specializing in group lending. PORVENIR's borrowers typically receive a six-month loan at a $3 \%$ interest rate with payments every two weeks. Loan size varies from 1,000 to 4,000 Bolivianos (US\$143 to US\$571) with larger sizes depending on borrowers' previous performance. Table 1 reports summary statistics of subject characteristics. Our sample was $87 \%$ female, with an average age of 37 years. About $65 \%$ of our subjects were married, $56 \%$ owned the house in which they lived, had an average of 8.5 years of formal education, and earned a household income of US \$193 per month. Within our sample, 122 out of 200 subjects were borrowers from delinquent groups in arrears with loan repayments. 
PORVENIR was not able to give us information about the specific circumstances about the role of each individual in a delinquent group. That a group under joint liability is in default means that borrowers in the group are unable to bring together the necessary funds required to make one or more joint-liability loan repayments. In this respect accountability for default is shared by all members of a defaulting group, both the borrowers within the group who fail to make cash available for their share of borrowed capital and their borrowing group partners who refuse to contribute to the troubled group loan. Although the behavior of these borrowers who fail to cover for partners' loans is arguably not the primary cause of the group default, it is certainly the secondary cause of the group default. Thus it is reasonable to assume that each member of a delinquent borrowing group embodies a greater average risk to a microfinance lender than members of borrowing groups who have never experienced repayment problems.

Therefore, in our analysis we consider a borrowing group member with a microfinance loan in arrears as a "risky" borrower. The non-risky subjects came from groups with no history of repayment problems. While any measure of borrower riskiness is imperfect, we have reason to believe ours is a good approximation capable of capturing important variations within the borrowing pool. ${ }^{2}$

Sample recruitment was carried out by PORVENIR's loan officers among their active borrowers, from either repaying or delinquent groups. Our sample does not contain members of completely defaulting groups, since these were no longer clients of the institution, but we cannot exclude the possibility that some of these delinquent groups might have become defaulting groups at a later date. PORVENIR officers were only involved in the recruitment phase of the experiment. They did not take any part in the data collection process, and they

\footnotetext{
${ }^{2}$ Research on group lending, such as Ghatak (1999) and Van Tassel (1999), has moreover argued that an important feature of joint-liability is that under self-selection groups should form homogeneously with respect to individual risk under an assortative matching process. While this formation process in practice is certainly imperfect, the point of their argument is well taken: there remains an incentive in group lending for high-risk borrowers to match with other high-risk borrowers, and low-risk to match with low-risk, where the homogeneity of groups ought to be commensurate with the level of information between borrowers about their types.
} 
were not present during any of the sessions and were not informed about individual experimental outcomes. The subjects were informed several times throughout the experiment that their choices would remain anonymous.

We carried out 17 sessions in total, where each session comprised of either 10 or 15 subjects. Depending on the outcome of the experiments, subjects earned payouts of up to 73 bolivianos (US\$10.50), more than one day's minimum salary where the monthly minimum wage was US\$92.5 in 2009. The sessions were held at the group's regular meeting place, typically the house of one of the group members.

\subsection{EXPERIMENTAL TREATMENTS}

The complete experimental design was comprised of seven different loan experimental treatments and a final risk aversion task. The experimental treatments were administered in random order and without revealing to the subject the results until the very end of the entire experiment to prevent wealth effects and correlation across treatments. Throughout the experiment the instructions were framed in the context of a microfinance loan (see Appendix). Under all of the loan treatments, each subject began the task with 500 bolivianos to be used as collateral for the securement of an experimental "loan" equal to 1000 bolivianos at $20 \%$ interest.

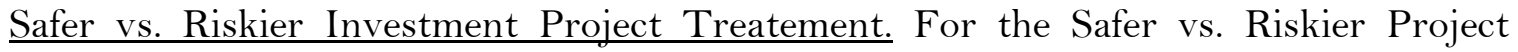
treatment, each subject had to choose between investing a loan in a safer project or into a riskier one. The Safer project, if successful, would return a gross payoff of 3,00o bolivianos. The probability of success was $5 / 6$, implemented by tossing a six-faced die in front of the subject if this task was the one randomly selected for payment at the end of the session. If the project failed (with 1/6 probability), the return was zero. In contrast, the Riskier project returned a gross payoff of 5,000 bolivianos or zero, each with probability 1/2. Again, the toss of the die (three faces were considered success, the other three failures) would occur in the 
presence of the subjects if selected for payment. Under either project, only in case of success would the subject be able to repay the principal of 1,000 bolivianos plus the 200 bolivianos in interest. Net profit would be 1,800 bolivianos, plus the 500 collateral, for a total of 2,300 bolivianos, in case the subject was successful and chose the Safer project, or 4,300 bolivianos (3,800 bolivianos plus the 500 collateral) if she chose the Riskier one. In cases of project failure, subjects would lose their 500 bolivianos collateral, and therefore would have earnings of zero. For more detailed explanations of the payoffs, refer to the Appendix where we provide a complete summary of our experimental protocol and instructions.

Consumption vs. Safer Investment Project. For the Consumption vs. Safer Investment Project, each subject had to choose between allocating her experimental loan either into a zero-risk project, which we framed in terms of "consumption," or "investment" in the safer project. The instructions specified that if a subject chose the low-payoff, zero-risk option (i.e. to consume the loan rather than investing it), she would keep the 1,000 bolivianos principal but would default on the loan and lose the 500 collateral. If a subject chose to invest, she would earn a gross payoff of 3,000 bolivianos (less the 1200 principal and interest payments) with 5/6 probability or zero with $1 / 6$ probability. Net profit would then be 2,300 in case of success (3,000 minus principal and interest, plus the collateral back), zero otherwise.

Our experimental tasks are very simple and, as such, are not intended to capture all aspects of lending dynamics. Repaid microfinance loans are typically rewarded with subsequent loans, and this may represent one of the most important motives for borrowers to repay a loan. We leave the dynamics out of our framework and develop a framework primarily designed to test the assumption that risky borrowers are associated with risky projects, not to directly assess the empirical validity of a particular behavioral-based credit theory. We believe this simplicity is a virtue, even as we acknowledge its shortcomings. For example, the choice to consume rather than invest could be due to extreme risk aversion (for which we control with 
the risk task), present bias, or a combination of the two. In a subsequent experiment one could introduce a time gap between the choice to consume and the one to invest, or a time elicitation component to the experiment, to account for the differences between extreme risk aversion and/or impatience. Here we implemented a static game with subject decisions made at a single point in time, where our experiment was designed in this way so that dynamic incentives, monitoring, and the other aspects of microfinance that are important in the real-world are held constant and identical between treatments.

Risk Task. To investigate the role that individual attitudes towards risk might have in being a risky or safe borrower, our experiment included a risk task to elicit an estimate of individual risk aversion. While it is still open to debate whether risk attitudes change in systematic ways in the aftermath of different life events or are a more permanent feature of an individual's personality (e.g. Cassar, Healy and von Kessler 2010), we could foresee the possibility that being part of a defaulting group could cause individual risk preferences to shift. If this were the case, a borrower's preference for "consumption" could be due to increased risk aversion instead of the other way round. Since we did not have any data on pre-delinquency risk attitudes, we cannot make any statement here about causality. We use our elicited estimates of risk aversion at the time of the experiment as control, aware that the causality could theoretically move in the opposite direction. Nevertheless, an uncontrolled $t$-test of riskaversion between borrowers from delinquent and non-delinquent groups shows no statistical difference between these groups (4.9 vs. 4.8 respectively, $p=0.62$ ), and when being in a delinquent group is regressed on the controls plus elicited risk aversion, parameters furthermore display non-significant results. Thus ex-post, after being already in a delinquent group, we see no difference in risk aversion between the two groups, but we cannot say anything about their ex-ante preferences.

From a procedural perspective, the risk task was administered at the end of the session 
before any of the actual outcomes of the previous experimental games were revealed to the subjects in order to prevent correlation between games. The protocol was based on the MPL (Multiple Price List) procedure of Holt and Laury (2002). The MPL protocol consists of presenting subjects with a series of choices between two distinct lotteries, Lottery A and Lottery B. The two payoffs of each lottery (one for the good outcome, one for the bad outcome) are constant, but the probabilities of success (good outcome) change from one round to the next. In our experiment, Lottery A offered the subjects an opportunity to gain either 2000 (experimental) bolivianos or 1600 bolivianos. ${ }^{3}$ Lottery B offered a higher gain of 3850 bolivianos in its high state, but only a 100-boliviano gain in its low state. Subjects had to decide which one of the two lotteries they preferred, one choice for each one of ten rounds in which the probability of the good outcome increased in increments of $10 \%$ from o to $100 \%$. Because probability is an abstract concept, lottery probabilities were explained to subjects in terms of frequencies with the help of colored balls as visual aids. Depending on the round in which a subject switched from Lottery A to Lottery B, we can infer individual risk preferences. (The later the round in which the subjects selected lottery $\mathrm{B}$, the higher is her estimated risk aversion). In case a subject switched back to Lottery A after having switched to Lottery B, we use the first time she switched to $\mathrm{B}$ as measure of her risk aversion, ${ }^{4}$ a common solution to this puzzling choice when using the MPL procedure (see Harrison and Rutström, 2008).

At the end of all the experimental tasks, subjects filled out a questionnaire covering age, gender, civil status, education, main occupation, income, expenditures, family size, assets, business activity, and home ownership.

\footnotetext{
${ }^{3}$ Payoffs from the experiments were given in experimental bolivianos at a conversion rate of 100 experimental bolivianos per actual boliviano. This was so experimenters could use integer numbers to make it easier for subjects. Subjects were informed about this conversion rate at the beginning and reminded throughout the session.

${ }^{4}$ Using either first switch time or an average does make a significant difference on our results.
} 


\section{EXPERIMENTAL RESULTS}

An uncontrolled $t$-test between "risky" borrowers and "safe" borrowers over their mean choice proportion between the riskier and safer investment projects reveals no significant difference between real-world delinquent and non-delinquent borrowers. Borrowers from delinquent groups chose the riskier project 29.8 percent of the time while those from good borrowing groups chose it 33.3 percent of the time $(p$-value $=0.597)$. If anything, the raw difference in outcomes contradicts the hypothesis that risky borrowers risk too much: they chose the riskier project less frequently and displayed more aversion (both differences insignificant, however, from an inferential perspective). However, in our second treatment, when the choice is between the zero-risk alternative (framed as consumption) and investment in a modestly risky project, borrowers from delinquent groups chose the first option at nearly twice the rate, 29.5 percent vs. 17.9 percent of the time by members of good borrowing groups $(p$-value $=0.066)$. One possibility we considered was that this difference could be due to subjects in the delinquent group not understanding the game as well as subjects from solvent groups; the consumption option in some respects was a more simple choice. However, if this were the cause, we would have found similar systematic group differences in the other treatments, especially in the risk task, but this is not the case. Furthermore, the result holds even after controlling for education, a variable likely to capture subjects' understanding of the respective experimental treatments.

Table 2 and Table 3 report the regression results for the experimental treatment outcomes. Table 2 displays the estimates for the Riskier vs. Safer Project treatment. Both the logit and linear probability estimations ${ }^{5}$ reveal that none of the independent variables display significant explanatory power except for risk aversion. Subjects who demonstrated a higher

\footnotetext{
${ }^{5}$ Given the relative low ratio of experimental sessions to subjects it would be inappropriate to use clustered standard errors.
} 
degree of risk aversion during the risk elicitation task were also less likely to choose the riskier project over the safer one: a one standard deviation increase in risk aversion decreases the probability of undertaking the riskier investment by about 6.2 percentage points, significant at the 90 percent confidence level. Thus when subjects are faced with choices that involve differing levels of implicit risk, individual risk preferences do matter and, as expected, more risk-averse subjects prefer the safer option. However, being a real-world risky borrower appears to have no significant effect on a subject's project choice.

Table 3 displays the results of the Consumption vs. Safer Project Investment treatment. On average, 25 percent of subjects preferred to consume rather than to invest. Importantly, those who might be outwardly identified as more reliable borrowers showed a stronger tendency toward investment than consumption. Subjects who owned a business were 22 percentage points less likely to choose to consume than those with only informal economic activity ( $p$-value $<0.01)$. Every year of additional education reduced the probability of choosing consumption by about 2 percentage points $(p$-value $<0.05)$

The most important result from this analysis is that real-word delinquent borrowers were significantly more likely to choose the consumption option over investment. The point estimate is large (12.8 percentage points more likely relative to a mean of 25 percent) and statistically significant $(p$-value $<0.05)$. Interestingly, the point estimates are essentially unchanged when we control for risk aversion, which becomes insignificant. This result casts doubt on the hypothesis that it is mainly risk aversion that induces delinquent borrowers to consume rather than to invest, in favor of alternative hypotheses (like present-bias) that are beyond the scope of the current experiment.

To summarize our results, our experimental results suggest that risky microfinance borrowers, those from delinquent borrowing groups, are not borrowers who invest in risky projects, but rather borrowers who are in some sense the opposite: they significantly prefer to 
consume loans instead of investing--even in a relatively safe project. Furthermore, our results show this may be partially due to some factor besides an unwillingness to take on enough of the risks associated with entrepreneurial activities. Leading possibilities are impatience or presentbias, and we leave the further exploration of this hypothesis for future work.

\section{Conclusion}

That the risky-project-based framework has enhanced our understanding of credit market failure does not necessarily render it a good framework for building applied models of credit markets in developing countries. Based on our experimental research, this may particularly hold for microfinance. Here, we argue that theories of credit markets centered in a riskyproject-based framework may be built on behavioral foundations that lack empirical and observational support. Although there are important facets of microfinance borrowing that are not captured in our simple experimental design (especially dynamic incentives), the simple choices and the frame we adopt in our protocol allows us to capture important differences in real-borrower characteristics.

If the implications of the traditional moral hazard models of credit rationing were to transfer to microfinance borrowers, we would expect to find real-world risky borrowers to prefer riskier projects over the safer ones. But this is not supported by our data. Controlling for risk-aversion, when faced with the experimental choice between a riskier project and a safer project, real-world risky borrowers are no more likely to expose themselves to risky projects than safe borrowers. In addition, again after controlling for risk-aversion, we find that these same borrowers are instead significantly more likely to choose the certainty of "consuming" a unit of capital over the small risk involved with choosing a relatively safe investment.

The assumptions behind models like Stiglitz and Weiss appear to be rooted in what an economic theorist can successfully argue should be a major source of moral hazard in credit 
markets. Yet our experimental research cannot confirm any relationship between the desire of borrowers to invest in projects with greater risk and actual problems in borrower repayment.

The traditional risk-based model has been widely used as a theoretical framework for understanding credit markets in developing countries and for economic analyses of microfinance. Here we propose an alternative explanation for moral hazard which has important policy implications for development practitioners. These differences, which we summarize in Table 4, are not benign. If the source of moral hazard we describe here more accurately reflects its true manifestation in credit markets, a persistent focus on "risky-versussafe projects" by microfinance institutions is likely to have little effect on addressing problems in poorly performing loan portfolios or under-performing credit institutions. For example, if the main problem facing a lender is the temptation for borrowers to divert borrowed capital away from productive investment toward present consumption, an emphasis on ensuring that projects are "safe" (say, in terms of variance in their gross returns) will be of little use in curtailing default.

Much of the more recent literature investigating credit market issues in developing countries and microfinance has explored self-control issues, nudges, and reference points as lying at the heart of savings and borrowing behavior (Bertrand et al., 2005; Ashraf et al., 2006; Gugerty, 2007). Our experiment offers modest support to the newer behavioral-economicsbased theories of borrower behavior, although an experiment designed to test these theories directly would better incorporate the dynamics and time lag involved in the consumption vs. investment decision.

Preliminary work from a separate experiment offers measured support for the idea that microfinance default may be associated with present bias. In a small study carried out among microfinance borrowers in Jordan, Start (2013) examines measures of riskiness and impatience and their relationship to microfinance default. In part of this study borrowers were asked the 
question "If you had two Kanafeh (a traditional Arab pastry soaked in a sweet syrup), would you eat both today, or eat one today and save the other for later?”. Microfinance borrowers with poor repayment records indicated they would eat the second Kanafeh today 41.7 percent of the time, while borrowers with excellent repayment records indicated they would eat the second Kanafeh today only 23.3 percent of the time. While regression on an aggregated index of impatience indicators is statistically insignificant, it provides an encouraging avenue for future research.

While the implications of the Stiglitz and Weiss model for credit rationing and market failure would generally not be considered neo-classical, their model assumes a quality of borrower rationality to which much of the behavioral economics literature has offered strong empirical challenges. Further work that incorporates behavioral economics into its research methodology will lead to the development of more robust models that not only allow us to understand the nature of borrower behavior in microfinance markets, but can be used to guide important policy questions faced by development practitioners.

\section{REFERENCES}

Aghion, B.A. \& Gollier, C. 2000, "Peer Group Formation in an Adverse Selection Model", Economic Journal, vol. 110, no. 465, pp. 632-643.

Aghion, B. \& Morduch, J. 2005, The Economics of Microfinance, MIT Press, Cambridge and London.

Ashraf, N. Karlan, D., and Yin, W. 2006, "Tying Odysseus to the Mast: Evidence From a Commitment Savings Product in the Philippines," Quarterly Journal of Economics, 12 1(2) 635-672.

Banerjee, A.V., Besley, T. and Guinnane, T.W. 1994, "Thy Neighbor's Keeper: The Design of a Credit Cooperative with Theory and a Test," Quarterly Journal of Economics, vol. 109, no. 2, pp. 491-515.

Banerjee, A., and Mullainathan, S. 2010, "The Shape of Temptation: Implications for the Economic Lives of the Poor," NBER Working Paper 15973.

Barboni., G. Cassar, A., Rodriguez, A. and Bruce Wydick, B. 2012. Adverse Selection and Moral Hazard in Joint-Liability Loan Contracts: Evidence from an Artefactual Field 
Experiment," Forthcoming, Journal of Economics and Management. (Special issue on using field experiments in economics and management.)

Bertrand, M. Karlin, D. Mullainathan, S., Shafir, E., and Zinman, J. (2005) "What's Psychology Worth? A Field Experiment in the Consumer Credit Market," NBER Working Paper No. 11892

Ghatak, M. 1999. "Group Lending, Local Information and Peer Selection," Journal of Development Economics, Vol. 60, 27-50

Ghatak, M. and Guinnane, T.W. 2001, "The Economics of Lending with Joint Liability: Theory and Practice," in D. Ray, ed., Readings in the Theory of Economic Development, New York: Blackwell

Giné, X., Jakiela, P., Karlan, D. and Morduch, J., 2010. "Microfinance Games," American Economic Journal: Applied Economics. 2(3), 60-95.

Gugerty, M. K., 2007. "You Can't Save Alone: Commitment in Rotating Savings and Credit Associations in Kenya," Economic Development and Cultural Change, 55(2), 251-282.

Harrison, G. and Rutström, E., 2008. "Risk Aversion in the Laboratory," in J.C. Cox and G.W. Harrison (eds.), Risk Aversion in Experiments (Bingley, UK: Emerald, Research in Experimental Economics, Volume 12, 2008).

Karlan, D. 2007, "Social Connections and Group Banking," Economic Journal, vol. 117, no. 517, pp. F52-84.

McIntosh, C., Villaran, G. and Wydick, B., 2011 . "Microfinance and Home Improvement: Using Retrospective Panel Data to Measure Program Effects on Fundamental Events," World Development (Symposium on Microfinance) 39(6) 922-937.

Start, Nike (2013) "Why Risk It? The Effect of Risk and Time Preferences on Microfinance Loan Default," University of San Francisco Masters Thesis.

Stiglitz, J.E. \& Weiss, A. 1981, "Credit Rationing in Markets with Imperfect Information," American Economic Review, vol. 71, no. 3, pp. 393-410.

Stiglitz, J.E. 1990, "Peer Monitoring and Credit Markets," World Bank Economic Review, vol. 4, no. 3, pp. 351-366.

Van Tassel, Eric. 1999, “Group Lending under Asymmetric Information,” Journal of Development Economics, vol. 60 pp. 3-25.

Wenner, M.D. 1995, "Group Credit: A Means to Improve Information Transfer and Loan Repayment Performance," Journal of Development Studies, vol. 32, no. 2, pp. 263-281.

Wydick, B. 2001 , "Group Lending under Dynamic Incentives as a Borrower Discipline Device," Review of Development Economics, vol. 5, no. 3, pp. 406-420.

Wydick, B. 1999, "Can Social Cohesion Be Harnessed to Repair Market Failures? Evidence from Group Lending in Guatemala," Economic Journal, vol. 109, no. 457, pp. 463-475.

Yunus, M. 1999, Banker to the Poor, New York: Public Affairs Press. 
Table 1: Summary statistics

\begin{tabular}{|c|c|c|c|c|}
\hline VARIABLES & $\begin{array}{c}\text { Mean } \\
\text { (Std.-Dev.) }\end{array}$ & $\begin{array}{c}\text { Risky } \\
\text { Borrowers } \\
(61 \%)\end{array}$ & $\begin{array}{c}\text { Safe } \\
\text { Borrowers } \\
(39 \%)\end{array}$ & $\begin{array}{c}\text { t-test } \\
\text { p-value } \\
\text { (two-tailed) }\end{array}$ \\
\hline $\begin{array}{l}\text { Risky Borrower } \\
\text { (from a delinquent group) }\end{array}$ & $\begin{array}{l}0.610 \\
(0.489)\end{array}$ & & & \\
\hline Female & $\begin{array}{l}0.870 \\
(0.337)\end{array}$ & $\begin{array}{l}0.869 \\
(0.339)\end{array}$ & $\begin{array}{l}0.872 \\
(0.336)\end{array}$ & 0.952 \\
\hline Age & $\begin{array}{l}37.270 \\
(12.713)\end{array}$ & $\begin{array}{l}37.115 \\
(12.625)\end{array}$ & $\begin{array}{l}37.513 \\
(12.928)\end{array}$ & 0.830 \\
\hline Married & $\begin{array}{l}0.650 \\
(0.478)\end{array}$ & $\begin{array}{l}0.648 \\
(0.480)\end{array}$ & $\begin{array}{l}0.654 \\
(0.479)\end{array}$ & 0.928 \\
\hline House owner & $\begin{array}{l}0.560 \\
(0.498)\end{array}$ & $\begin{array}{l}0.525 \\
(0.501)\end{array}$ & $\begin{array}{l}0.615 \\
(0.490)\end{array}$ & 0.209 \\
\hline Persons per room & $\begin{array}{l}2.886 \\
(1.751)\end{array}$ & $\begin{array}{l}2.863 \\
(1.886)\end{array}$ & $\begin{array}{l}2.923 \\
(1.527)\end{array}$ & 0.814 \\
\hline Subject owns business & $\begin{array}{l}0.535 \\
(0.500)\end{array}$ & $\begin{array}{l}0.590 \\
(0.494)\end{array}$ & $\begin{array}{l}0.449 \\
(0.501)\end{array}$ & $0.051^{*}$ \\
\hline $\begin{array}{l}\text { Income proxy } \\
\text { (expenditures - Bolivianos) }\end{array}$ & $\begin{array}{l}1350.047 \\
(1546.523)\end{array}$ & $\begin{array}{l}1302.451 \\
(1389.762)\end{array}$ & $\begin{array}{l}1424.492 \\
(1771.134)\end{array}$ & 0.588 \\
\hline Years of education & $\begin{array}{l}8.505 \\
(4.128) \\
\end{array}$ & $\begin{array}{l}8.025 \\
(4.079) \\
\end{array}$ & $\begin{array}{l}9.256 \\
(4.120) \\
\end{array}$ & $0.039^{*} *$ \\
\hline \multicolumn{5}{|c|}{ EXPERIMENTAL RESULTS } \\
\hline $\begin{array}{l}\text { Risk Aversion } \\
\text { (experimental elicitation) }\end{array}$ & $\begin{array}{l}4.830 \\
(1.690)\end{array}$ & $\begin{array}{l}4.877 \\
(1.756)\end{array}$ & $\begin{array}{l}4.756 \\
(1.589)\end{array}$ & 0.624 \\
\hline Consume vs. Safer project & $\begin{array}{l}0.250 \\
(0.434)\end{array}$ & $\begin{array}{l}0.295 \\
(0.458)\end{array}$ & $\begin{array}{l}0.179 \\
(0.386)\end{array}$ & $0.066^{*}$ \\
\hline Riskier vs. Safer project & $\begin{array}{l}0.312 \\
(0.464)\end{array}$ & $\begin{array}{l}0.298 \\
(0.459)\end{array}$ & $\begin{array}{l}0.333 \\
(0.474)\end{array}$ & 0.597 \\
\hline
\end{tabular}

Standard deviations in parentheses 
Table 2: Results of Riskier vs. Safer Investment Treatment

Dep. Variable: $1=$ Subject choses riskier over safer project (mean 0.312, std. dev. 0.464)

\begin{tabular}{|c|c|c|c|c|c|c|}
\hline VARIABLES & \multicolumn{3}{|c|}{$\begin{array}{l}\text { Logit Estimations } \\
\text { (marginal effects) }\end{array}$} & \multicolumn{3}{|c|}{ Linear Probability Model } \\
\hline $\begin{array}{l}\text { Risky Borrower } \\
\text { (from a delinquent group) }\end{array}$ & $\begin{array}{l}-0.036 \\
(0.068)\end{array}$ & $\begin{array}{r}-0.032 \\
(0.071)\end{array}$ & $\begin{array}{r}-0.029 \\
(0.071)\end{array}$ & $\begin{array}{l}-0.036 \\
(0.068)\end{array}$ & $\begin{array}{r}-0.032 \\
(0.071)\end{array}$ & $\begin{array}{r}-0.028 \\
(0.071)\end{array}$ \\
\hline Female & & $\begin{array}{l}-0.078 \\
(0.107)\end{array}$ & $\begin{array}{l}-0.066 \\
(0.106)\end{array}$ & & $\begin{array}{l}-0.077 \\
(0.103)\end{array}$ & $\begin{array}{l}-0.065 \\
(0.103)\end{array}$ \\
\hline Age & & $\begin{array}{l}0.003 \\
(0.003)\end{array}$ & $\begin{array}{l}0.002 \\
(0.003)\end{array}$ & & $\begin{array}{l}0.003 \\
(0.003)\end{array}$ & $\begin{array}{l}0.002 \\
(0.003)\end{array}$ \\
\hline Married & & $\begin{array}{l}0.000 \\
(0.072)\end{array}$ & $\begin{array}{l}0.017 \\
(0.073)\end{array}$ & & $\begin{array}{l}0.000 \\
(0.073)\end{array}$ & $\begin{array}{l}0.017 \\
(0.073)\end{array}$ \\
\hline House owner & & $\begin{array}{l}0.062 \\
(0.068)\end{array}$ & $\begin{array}{l}0.073 \\
(0.068)\end{array}$ & & $\begin{array}{l}0.063 \\
(0.069)\end{array}$ & $\begin{array}{l}0.073 \\
(0.069)\end{array}$ \\
\hline Persons per room & & $\begin{array}{l}0.009 \\
(0.019)\end{array}$ & $\begin{array}{l}0.007 \\
(0.019)\end{array}$ & & $\begin{array}{l}0.010 \\
(0.020)\end{array}$ & $\begin{array}{l}0.007 \\
(0.020)\end{array}$ \\
\hline Subject owns business & & $\begin{array}{l}0.037 \\
(0.071)\end{array}$ & $\begin{array}{l}0.042 \\
(0.071)\end{array}$ & & $\begin{array}{l}0.036 \\
(0.072)\end{array}$ & $\begin{array}{l}0.043 \\
(0.071)\end{array}$ \\
\hline $\begin{array}{l}\text { Income proxy } \\
\text { (expenditures - Bolivianos) }\end{array}$ & & $\begin{array}{r}-0.022 \\
(0.027)\end{array}$ & $\begin{array}{r}-0.024 \\
(0.027)\end{array}$ & & $\begin{array}{r}-0.022 \\
(0.028)\end{array}$ & $\begin{array}{l}-0.024 \\
(0.028)\end{array}$ \\
\hline Years of education & & $\begin{array}{l}0.006 \\
(0.010)\end{array}$ & $\begin{array}{l}0.006 \\
(0.010)\end{array}$ & & $\begin{array}{l}0.006 \\
(0.010)\end{array}$ & $\begin{array}{l}0.006 \\
(0.010)\end{array}$ \\
\hline $\begin{array}{l}\text { Risk Aversion } \\
\text { (experimental elicitation) }\end{array}$ & & & $\begin{array}{c}-0.0354^{*} \\
(0.020)\end{array}$ & & & $\begin{array}{c}-0.0365^{*} \\
(0.020)\end{array}$ \\
\hline Constant & & & & $\begin{array}{c}0.333^{* * *} * \\
(0.053)\end{array}$ & $\begin{array}{l}0.288 \\
(0.288)\end{array}$ & $\begin{array}{l}0.494 \\
(0.308)\end{array}$ \\
\hline Observations & 199 & 199 & 199 & 199 & 199 & 199 \\
\hline Pseudo R2 & 0.001 & 0.896 & 0.030 & & & \\
\hline R-Squared & & & & 0.001 & 0.021 & 0.038 \\
\hline Adj R-Squared & & & & -0.004 & -0.025 & -0.013 \\
\hline
\end{tabular}

Standard errors in parentheses

**** $\mathrm{p}<0.01$, ** $\mathrm{p}<0.05$, $* \mathrm{p}<0.1$ 
Table 3: Results of Consumption vs. Investment Treatment

Dep. Variable: $1=$ Subject choses consumption vs. safer project (mean 0.25, std. dev. 0.434)

\begin{tabular}{|c|c|c|c|c|c|c|}
\hline VARIABLES & \multicolumn{3}{|c|}{$\begin{array}{l}\text { Logit Estimations } \\
\text { (marginal effects) }\end{array}$} & \multicolumn{3}{|c|}{ Linear Probability Model } \\
\hline $\begin{array}{l}\text { Risky Borrower } \\
\text { (from a delinquent group) }\end{array}$ & $\begin{array}{l}0.116^{*} \\
(0.060)\end{array}$ & $\begin{array}{l}\text { O.128** } \\
(0.059)\end{array}$ & $\begin{array}{l}0.127^{* *} \\
(0.059)\end{array}$ & $\begin{array}{l}0.116^{*} \\
(0.063)\end{array}$ & $\begin{array}{l}\text { O. } 129 * * \\
(0.062)\end{array}$ & $\begin{array}{l}0.128^{* *} \\
(0.062)\end{array}$ \\
\hline Female & & $\begin{array}{l}0.079 \\
(0.088)\end{array}$ & $\begin{array}{l}0.078 \\
(0.089)\end{array}$ & & $\begin{array}{l}0.072 \\
(0.090)\end{array}$ & $\begin{array}{l}0.070 \\
(0.090)\end{array}$ \\
\hline Age & & $\begin{array}{l}0.003 \\
(0.003)\end{array}$ & $\begin{array}{l}0.003 \\
(0.003)\end{array}$ & & $\begin{array}{l}0.003 \\
(0.003)\end{array}$ & $\begin{array}{l}0.003 \\
(0.003)\end{array}$ \\
\hline Married & & $\begin{array}{l}0.013 \\
(0.065)\end{array}$ & $\begin{array}{l}0.011 \\
(0.066)\end{array}$ & & $\begin{array}{l}0.013 \\
(0.063)\end{array}$ & $\begin{array}{l}0.010 \\
(0.064)\end{array}$ \\
\hline House owner & & $\begin{array}{l}-0.024 \\
(0.062)\end{array}$ & $\begin{array}{r}-0.025 \\
(0.063)\end{array}$ & & $\begin{array}{r}-0.013 \\
(0.060)\end{array}$ & $\begin{array}{r}-0.015 \\
(0.060)\end{array}$ \\
\hline Persons per room & & $\begin{array}{r}-0.004 \\
(0.018)\end{array}$ & $\begin{array}{r}-0.003 \\
(0.018)\end{array}$ & & $\begin{array}{r}-0.003 \\
(0.017)\end{array}$ & $\begin{array}{l}-0.002 \\
(0.017)\end{array}$ \\
\hline Subject owns business & & $\begin{array}{c}-0.227^{* * * *} \\
(0.067)\end{array}$ & $\begin{array}{c}-0.227^{*} * * \\
(0.067)\end{array}$ & & $\begin{array}{c}-0.223^{* * *} \\
(0.062)\end{array}$ & $\begin{array}{c}-0.224^{* * *} * \\
(0.062)\end{array}$ \\
\hline $\begin{array}{l}\text { Income proxy } \\
\text { (expenditures - Bolivianos) }\end{array}$ & & $\begin{array}{l}0.019 \\
(0.026)\end{array}$ & $\begin{array}{l}0.019 \\
(0.026)\end{array}$ & & $\begin{array}{l}0.021 \\
(0.024)\end{array}$ & $\begin{array}{l}0.021 \\
(0.024)\end{array}$ \\
\hline Years of education & & $\begin{array}{c}-0.0168^{*} \\
(0.009)\end{array}$ & $\begin{array}{c}-0.0167^{*} \\
(0.009)\end{array}$ & & $\begin{array}{c}-0.0192^{* *} \\
(0.009)\end{array}$ & $\begin{array}{c}-0.0192^{* *} \\
(0.009)\end{array}$ \\
\hline $\begin{array}{l}\text { Risk Aversion } \\
\text { (experimental elicitation) }\end{array}$ & & & $\begin{array}{l}0.003 \\
(0.018)\end{array}$ & & & $\begin{array}{l}0.006 \\
(0.018)\end{array}$ \\
\hline Constant & & & & $\begin{array}{c}0.179^{* * * *} \\
(0.049)\end{array}$ & $\begin{array}{c}0.140 \\
(0.248)\end{array}$ & $\begin{array}{c}0.105 \\
(0.267)\end{array}$ \\
\hline Observations & 200 & 200 & 200 & 200 & 200 & 200 \\
\hline Pseudo $\mathrm{R} 2$ & 0.016 & 0.143 & 0.143 & & & \\
\hline R-Squared & & & & 0.017 & 0.156 & 0.156 \\
\hline Adj R-Squared & & & & 0.012 & O. 1156 & 0.112 \\
\hline
\end{tabular}

Standard errors in parentheses

*** $\mathrm{p}<0.01$, ** $\mathrm{p}<0.05$, $* \mathrm{p}<0.1$ 
Table 4: Policy Implications Consequences

\begin{tabular}{llll}
\hline Concern & $\begin{array}{l}\text { Policy Implications of } \\
\text { Traditional Model }\end{array}$ & $\begin{array}{l}\text { Policy Implications of } \\
\text { Present Bias Model }\end{array}$ & $\begin{array}{l}\text { Consequences of } \\
\text { Incorrect Policy }\end{array}$ \\
\hline Borrower Selection & $\begin{array}{l}\text { Screening should occur } \\
\text { over borrower projects }\end{array}$ & $\begin{array}{l}\text { Screening should occur } \\
\text { over borrower } \\
\text { entrepreneurialism }\end{array}$ & $\begin{array}{l}\text { Emphasis on decreasing } \\
\text { risk dissuades } \\
\text { entrepreneurship }\end{array}$ \\
\hline Borrower Behavior & $\begin{array}{l}\text { Repayment will be higher } \\
\text { if borrowers have low risk } \\
\text { projects }\end{array}$ & $\begin{array}{l}\text { Repayment high if } \\
\text { borrower fully invest in } \\
\text { projects }\end{array}$ & $\begin{array}{l}\text { Safe projects will not } \\
\text { guarantee loan repayment }\end{array}$ \\
\hline Borrower Training & $\begin{array}{l}\text { Borrowers should be } \\
\text { dissuaded from } \\
\text { undertaking risky projects }\end{array}$ & $\begin{array}{l}\text { Borrowers should be } \\
\text { encouraged to invest } \\
\text { boldly and productively }\end{array}$ & $\begin{array}{l}\text { Consumption-based moral } \\
\text { hazard not addressed }\end{array}$ \\
\hline Credit Officer Training & $\begin{array}{l}\text { Train credit officers to } \\
\text { screen risky borrower } \\
\text { projects from portfolio }\end{array}$ & $\begin{array}{l}\text { Train credit officers to } \\
\text { encourage clients' } \\
\text { productive investment }\end{array}$ & $\begin{array}{l}\text { Lender stifles } \\
\text { entrepreneurial } \\
\text { development among } \\
\text { clients }\end{array}$ \\
\hline Savings Mobilization & $\begin{array}{l}\text { No particular emphasis on } \\
\text { savings versus household } \\
\text { consumption }\end{array}$ & $\begin{array}{l}\text { Encourage the self- } \\
\text { discipline of regular } \\
\text { savings by clients }\end{array}$ & $\begin{array}{l}\text { Borrowers aren't } \\
\text { supported in developing } \\
\text { savings discipline }\end{array}$ \\
\hline Overall Theme & Discourage risk-taking & Promote investment & Higher Default Rates \\
\hline
\end{tabular}




\section{Appendix: Experiment Protocol and Instructions (To be available on-line)}

\section{Welcome Announcement}

Hi and thank you for being here today!

Let's start by introducing our research team: Eliana Zeballos, Giorgia Barboni y Arturo Rodriguez. If, at any point in the future, you would like to contact us or know more about this study, feel free to contact the main researcher responsible for this study: Alessandra Cassar, Associate Professor, Department of Economics, University of San Francisco, 21300 Fulton Street, San Francisco, CA 94117-1080. Tel.(415)422-5351; Email: acassar@usfca.edu

Thank you for agreeing to participate in this study that concerns the economics of decision making. Your participation in this experiment is voluntary. However, we think you will find the experiment interesting. You could make a considerable amount of money in this experiment in addition to the participation fee. This additional amount of money depends partly on the choices you make in the activities that follow and partly on your luck.

These activities are not designed to test you or your knowledge. What we want to know is what choices you prefer. The only right answer is what you really want to choose in a given situation. These activities give you the chance of winning real money, so think hard about what choice you want to make in each activity.

By signing the informed consent form you indicate your willingness to participate in the full length of the experiment, which will take approximately three hours. Is everyone still able to stay for the full three hours?

This study will consist of a series of 8 activities and a final survey. You will be given instructions for each activity and we will read them together. The instructions are simple and you will benefit from following them carefully. Also we will conduct practice rounds for each task.

For each of the activities you will be asked to make one or more decisions. At the end of the 8 tasks and the survey, you will draw a chip from a black bag; this bag has eight chips representing each of the 8 tasks that we will conduct. Your payment will be determined by eliminating two zeros from the results of the final round of the activity indicated by the chip you drew. We will ask you to step aside for a moment and then call you back in, one at a time, to pay you in private.

Thank you for your participation! 


\section{Instructions for Activity $\mathbf{C 1}$}

[MATERIAL: One six-face die]

[SUBJECTS ARRANGEMENT: As the subjects enter the room (or reenter from a break), they sit in rows away from each other to listen to the instructions. Once the instructions, the examples and the quiz are over, the subjects turn around so they cannot see each other any longer.]

As we explained before, at the end of the 8 activities, one activity will be chosen by having you draw a chip from a bag. If the chip is $\mathrm{C} 1$ you will be paid in cash according to the earnings you gain in this activity. Remember that the final payoff is calculated eliminating two zeros from the result of the Final Round of this activity.

\section{Activity $\mathbf{C 1}$}

For this activity, each one of you will be a borrower. Everyone starts with a 500 bolivianos initial endowment that will be used as collateral for the loan that you are about to receive. Each loan is 1000 bolivianos and it needs to be repaid at a $20 \%$ interest rate. The repayment will then be 1200 bolivianos.

The activity consists of deciding what to do with your loan. You have 2 options: Project C and the Project S.

You can either consume your loan (by choosing Project C) or invest it (by choosing Project S). If you choose to invest your loan, you will have to roll the die to see if your project is a success or a failure.

The consumption activity (Project $\mathbf{C})$ yields a gross return of 1500 bolivianos FOR SURE. If you choose this project, it means that you are using your loan to buy products or services that don't generate any kind of return, and therefore, you will not have sufficient funds to repay the loan. Since you are NOT repaying your loan, the microfinance institution will keep your initial 500 bolivianos collateral. Your net return will then be 1500 bolivianos $(500+1500-$ $500=1500)$ :

\begin{tabular}{|c|l|c|l|}
\hline Project & Probability & Gross Return & Net Return \\
\hline C & 1 & 1500 & $500+1500-500=\mathbf{1 5 0 0}$ \\
\hline
\end{tabular}

The investment activity (Project $\mathbf{S}$ ) yields a gross return of 3000 bolivianos if by rolling the die you get a 1,2,3,4 or 5 . If this is the case, you will have to repay 1200 bolivianos for your loan but you will keep your collateral of 500 bolivianos since you pay on time. Your net return will then be 2300 bolivianos $(=500+3000-1200)$.

However, if you chose Project $\mathbf{S}$ and the die lands on a 6, your project fails and you will not receive anything. In this case, you will not be able to repay your loan and you will lose your 500 bolivianos of collateral. Your net return in this case would be $\mathrm{O}(=500+0-500)$. 


\begin{tabular}{|c|c|c|c|}
\hline Project & Probability & Gross Return & Net Return \\
\hline \multirow{2}{*}{$\mathrm{S}$} & 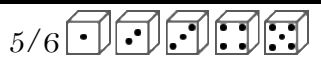 & 3000 & $500+3000-1200=\mathbf{2 3 0 0}$ \\
\hline & $1 / 6$ 国 & 0 & $500+0-500=0$ \\
\hline
\end{tabular}

\section{Practice Runs}

[Each subject is asked to choose $C$ and calculate returns.

Each subject is asked to choose $S$, roll a die and calculate returns.]

\section{Quiz}

If you choose $\mathrm{S}$ and you roll a 3. How much do you get, o or 2300 ?

If you choose $\mathrm{S}$ and you roll a 6 . How much do you get, $\mathrm{O}$ or 2300 ?

How much do you earn if you choose C?

[Each subject is asked to choose C or $S$ in their answer sheet] 


\section{Instructions for Activity $\mathbf{C 2}$}

[MATERIAL: One six-face die]

[SUBJECTS ARRANGEMENT: As the subjects enter the room (or reenter from a break), they sit in rows away from each other to listen to the instructions. Once the instructions, the examples and the quiz are over, the subjects turn around so they cannot see each other any longer.]

As we explained before, at the end of the 8 activities, one activity will be chosen by having you draw a chip from a bag. If the chip is $\mathrm{C} 2$ you will be paid in cash according to the earnings you gain in this activity. Remember that the final payoff is calculated eliminating two zeros from the result of the Final Round of this activity.

\section{Activity C2}

For this activity, each one of you will be a borrower. Everyone starts with a 500 bolivianos initial endowment that will be used as collateral for the loan that you are about to receive. Each loan is 1000 bolivianos and it needs to be repaid at a $20 \%$ interest rate. The repayment will then be 1200 bolivianos.

The activity consists of deciding what to do with your loan. You can invest your loan in 2 options: Project M or Project R.

The investment activity in Project $\mathbf{M}$ yields a gross return of 3000 bolivianos if by rolling the die you get a 1, 2, 3, 4 or 5 . If this is the case, you will have to repay 1200 bolivianos for your loan but you will keep your collateral of 500 bolivianos since you pay on time. Your net return will then be 2300 bolivianos $(=500+3000-1200)$.

However, if the die lands on a 6 , your project fails and you will not receive anything. In this case, you will not be able to repay your loan and you will lose your 500 bolivianos of collateral. Your net return in this case would be $\mathrm{O}(=500+0-500)$.

\begin{tabular}{|c|c|c|c|}
\hline Project & Probability & Gross Return & Net Return \\
\hline \multirow{2}{*}{ M } & 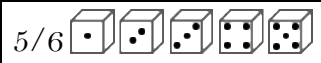 & 3000 & $500+3000-1200=\mathbf{2 3 0 0}$ \\
\hline & $1 / 6$ : & 0 & $500+0-500=\mathbf{0}$ \\
\hline
\end{tabular}

On the other hand, the investment activity in Project $\mathbf{R}$ yields a gross return of 5000 bolivianos if by rolling the die you get a 1, 2, or 3 . If this is the case, you will have to repay 1200 bolivianos for your loan but you will keep your collateral of 500 bolivianos since you pay on time. Your net return will then be 4300 bolivianos $(=500+5000-1200)$.

However, if the die lands on a 4, 5 or 6 , your project fails and you will not receive anything. In this case, you will not be able to repay your loan and you will lose your 500 bolivianos of collateral. Your net return in this case would be $0(=500+0-500)$. 


\begin{tabular}{|c|c|c|c|}
\hline Project & Probability & Gross Return & Net Return \\
\hline \multirow{2}{*}{$\mathrm{R}$} & ${ }_{1 / 2} \bullet \bullet \mid \cdot \bullet$ & 5000 & $500+5000-1200=\mathbf{4 3 0 0}$ \\
\hline & 1/2 $\because \because: \because: 0$ & 0 & $500+0-500=\mathbf{0}$ \\
\hline
\end{tabular}

\section{Practice Runs}

[Each subject is asked to choose $M$, roll a die and calculate returns.

Each subject is asked to choose $R$, roll a die and calculate returns.]

\section{Quiz}

If you choose the project $\mathrm{M}$ and you roll a 3. How much do you get, $\mathrm{O}$ or 2300 ?

If you choose the project $\mathrm{M}$ and you roll a 5. How much do you get, $\mathrm{O}$ or 2300 ?

If you choose the project $\mathrm{R}$ and you roll a 4 . How much do you get, $\mathrm{O}$ or 4300 ?

If you choose the project $\mathrm{R}$ and you roll a 1 . How much do you get, $\mathrm{O}$ or 4300 ?

[Each subject is asked to choose $M$ or $R$ in their answer sheet] 


\section{Instructions for Activity C8 (Risk Elicitation Task)}

[MATERIAL: Ten red chips, ten green chips, two bags, ten blue chips numbered from 1 to 10]

[SUBJECTS ARRANGEMENT: As the subjects enter the room (or reenter from a break), they sit in rows away from each other to listen to the instructions. Once the instructions, the examples and the quiz are over, the subjects turn around so they cannot see each other any longer.]

As we explained before, at the end of the 8 activities, one activity will be chosen by having you draw a chip from a bag. If the chip is $\mathrm{C} 8$ you will be paid in cash according to the earnings you gain in this activity. Remember that the final payoff is calculated eliminating two zeros from the result of the final round of this activity.

\section{Activity C8}

For this activity we have 10 imaginary bags. Each one contains chips of two different colors: green and red. A green chip will always represent a higher payoff than a red chip. Bag 1, for example, has one green chip and nine red ones. Bag 5 has five green chips and five red ones. The last bag, Bag 10, has ten green chips and no red ones.

In this game you have ten decisions to make, one for each imaginary bag. You will be asked to choose either Option A or Option B. If you choose Option A your payoff could result in either 2000 bolivianos or 1600 bolivianos. On the other hand, if you choose Option B your payoff could result in either 3850 bolivianos or 100 bolivianos. Please note that the potential payoffs for Options A and B are exactly the same for all the imaginary bags.

Once you have made your choices for each of the imaginary bags, you will draw one chip from two different bags to calculate your final payoff:

The first bag will have ten chips numbered from 1 to 10 . These chips represent each of the ten imaginary bags: a chip with the number one, for example, represents Bag 1 where there is one green chip. A chip with the number 5 represents Bag 5 where there are five green chips, and so on. Finally, a chip with the number 10 represents Bag 10 where there are only green chips.

Ultimately, the number on the chip you draw from the first bag represents the number of green chips that will be included in the second bag. Again, if you draw a chip with number one, the second bag will have one green chip and 9 red ones; if you draw a chip with number 5 , the second bag will include 5 green chips and 5 red ones. If you draw chip number 10, the second bag will consist of only 10 green chips and no red ones.

Your payoff will depend on two things: first, the Option (A or B) that you have chosen for the bag represented by the chip you draw from the first bag; and, second, the color of the chip (green or red) that you draw from the second bag. For example, let's suppose you draw a chip with number 5 from the first bag and then a green chip from the second bag. If during the game you chose Option A for Bag 5 your payoff will be 2000 bolivianos; if you chose Option B, your payoff will be 3850 . However, note that if you draw a red chip from the second bag, your payoff will be 1600 bolivianos if you chose Option A or 100 bolivianos if you chose Option B. 
The table that we have installed in the front of the room will help you make your decisions. Remember that there are no correct or incorrect answers. The decisions you make should depend only on what you think is best for you.

\begin{tabular}{|c|c|c|c|c|c|c|}
\hline \multirow[b]{2}{*}{$B A G$} & \multirow[b]{2}{*}{ Green Balls } & \multirow[b]{2}{*}{ Red Balls } & \multicolumn{2}{|c|}{ OPTION A } & \multicolumn{2}{|c|}{ OPTION B } \\
\hline & & & If green & If red & If green & If red \\
\hline 1 & 1 & 9 & \multirow{10}{*}{2000} & \multirow{10}{*}{1600} & \multirow{10}{*}{3850} & \multirow{10}{*}{100} \\
\hline 2 & 2 & 8 & & & & \\
\hline 3 & 3 & 7 & & & & \\
\hline 4 & 4 & 6 & & & & \\
\hline 5 & 5 & 5 & & & & \\
\hline 6 & 6 & 4 & & & & \\
\hline 7 & 7 & 3 & & & & \\
\hline 8 & 8 & 2 & & & & \\
\hline 9 & 9 & 1 & & & & \\
\hline 10 & 10 & $\mathrm{O}$ & & & & \\
\hline
\end{tabular}

\section{Practice Runs}

[All participants will be asked to choose Option A for all the imaginary bags and then draw one chip from the first bag and a second chip from the second bag. Payoffs are calculated.

All participants are asked to choose Option B for all the imaginary bags and then draw one chip from the first bag and a second chip from the second bag. Payoffs are calculated.

All participants are asked to choose Option B up to Bag 5 and Option A from Bag 6 onwards. Then a chip is drawn from the first bag and another from the second bag to calculate payoffs.]

\section{Quiz}

1. How much would your payoff be if you chose Option A for all the imaginary bags, and then the chip you draw from the first bag has the number 1 and the one you draw from the second bag is green?

2. How much would your payoff be if you chose Option A for all the imaginary bags, and then the chip you draw from the first bag has the number 1 and the one you draw from the second bag is red?

3. How much would your payoff be if you chose Option B for all the imaginary bags, and then the chip you draw from the first bag has the number 1 and the one you draw from the second bag is green?

4. How much would your payoff be if you chose Option B for all the imaginary bags, and then the chip you draw from the first bag has the number 1 and the one you draw from the second bag is red? 
How to calculate the final payment?

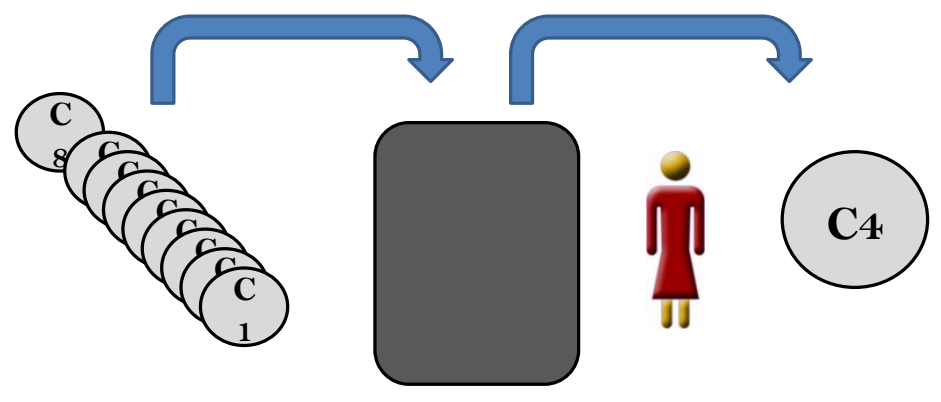

\section{Outcome $\mathrm{C}_{2} \rightarrow 2300$ $230 \mathrm{\alpha}=23 \mathrm{Bs}+30 \mathrm{Bs}=53 \mathrm{Bs}$}

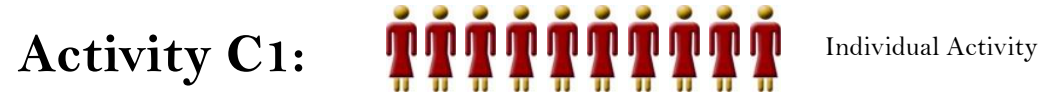

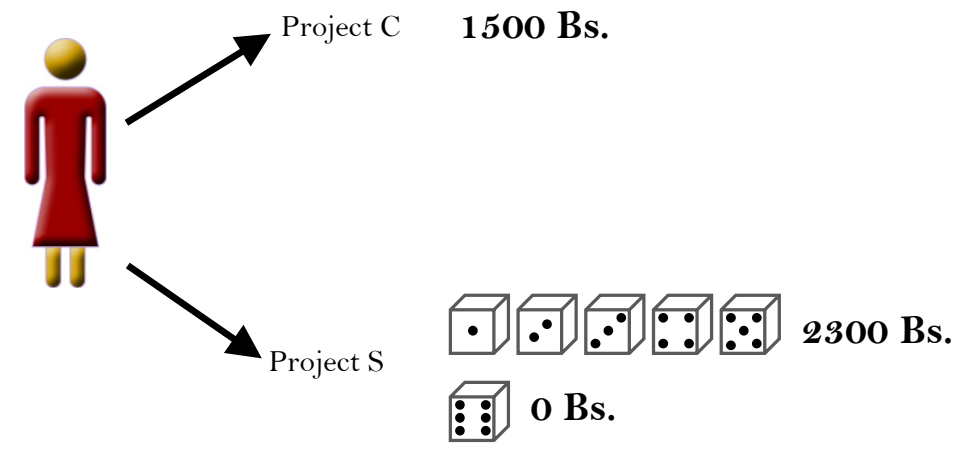




\section{Activity C2: $\quad$ minn}

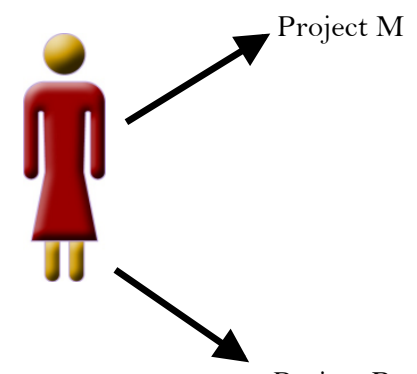

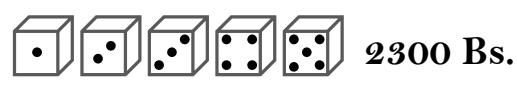

: 0 Bs.

$[0.004300 \mathrm{Bs}$.

Project R

$\because \because \because: \because 0$ Bs.

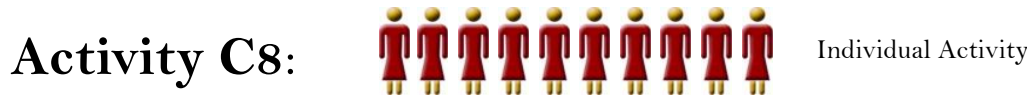

\begin{tabular}{|c|c|c|c|c|c|c|}
\hline \multirow[b]{2}{*}{ BAG } & \multirow[b]{2}{*}{$\begin{array}{c}\# \\
\text { Green Balls }\end{array}$} & \multirow[b]{2}{*}{$\begin{array}{c}\# \\
\text { Red Balls }\end{array}$} & \multicolumn{2}{|c|}{ OPTION A } & \multicolumn{2}{|c|}{ OPTION B } \\
\hline & & & Payment & Payment & Payment & Payment \\
\hline 1 & 1 & 9 & 2000 & 1600 & 3850 & 100 \\
\hline 2 & 2 & 8 & 2000 & 1600 & 3850 & 100 \\
\hline 3 & 3 & 7 & 2000 & 1600 & 3850 & 100 \\
\hline 4 & 4 & 6 & 2000 & 1600 & 3850 & 100 \\
\hline 5 & 5 & 5 & 2000 & 1600 & 3850 & 100 \\
\hline 6 & 6 & 4 & 2000 & 1600 & 3850 & 100 \\
\hline 7 & 7 & 3 & 2000 & 1600 & 3850 & 100 \\
\hline 8 & 8 & 2 & 2000 & 1600 & 3850 & 100 \\
\hline 9 & 9 & 1 & 2000 & 1600 & 3850 & 100 \\
\hline 10 & 10 & 0 & 2000 & 1600 & 3850 & 100 \\
\hline
\end{tabular}

